\title{
Shortfall of Strategic Governance and Strategic Management in the Czech Republic
}

\begin{abstract}
The article analyses the problems of strategic governance and strategic management of the Czechoslovak Government, as well as the Government of the Czech Republic in the years 1989-2016. It seeks the causes and factors that have caused the low levels of strategic governance and strategic management at the level of the ministries of the Czech Republic. It examines the problem from genetic and historical perspective, and from the organizational and human capacity to exercise strategic governance. The study is based on two pieces of empirical research within the ministries of the Czech Republic. It identifies the main cause of failure of strategic governance and strategic management at the level of the central government of the Czech Republic. These include, in particular, the persistent distrust of the ideas of strategic governance and strategic management held by the right-wing governments and the generally low capacity of governments of the Czech Republic to engage in strategic governance. The organizational structure of the central state administration lacks the strategic units that generate ideas for supporting strategic governance. The empirical research of the ministries of the Czech Republic also revealed that policy workers in Czech ministries dedicate a large proportion of their work time to operational and administrative activities at the expense of analytical and strategic activities. The changes require implementation of reforms within the public administration, which (among other things) will eliminate the existing causes and inhibiting factors regarding the lack of strategic governance in the Czech Republic.
\end{abstract}

KEYWORDS: strategic governance, strategic management, governments, ministries, the Czech Republic.

RECEIVED 12 February 2015; ACCEPTED 29 September 2016.

\section{INTRODUCTION}

Within the theory of the last decade, we find different approaches that deal with the question of how to streamline governance and public sector management (see de Vries \& Nemec, 2013). In our study, we started from the premise that one of the tools to streamline governance is the implementation of the ideas of 'strategic governance' and 'strategic management in society.' This assumption derives from the extension and intension concept of 'good governance' (see Governance, 2000). Strategic governance and strategic management are, in fact, instruments 'to influence the future for the better' (Dror, 2004) and to implement it through a 'strategic plan' (Harris, 2005). The government, which wants to be 'at the mercy of events', should be able to anticipate trends and evaluate the consequences of their decisions (and non-decisions) to the society. Such an activity can be fulfilled by such a government, based on the principles of strategic governance and strategic management (see Potůček et al., 2007).

While searching for the theoretical basis for an analysis of strategic governance, however, we confronted the problem of professional literature not having explicitly addressed the definition of relationship between the terms 'governance' and 'strategic governance'. Authors who deal with the problem of strategic governance have not defined the relationship between these concepts explicitly. Our investigation was not able to latch onto any reference to a pre-defined relationship between the terms 'governance' and 'strategic governance'. On the basis of existing scientific debate, it is therefore for the purposes of our study, that we will endeavour to define the relationship between the terms 'governance' and 'strategic governance' in theoretical and conceptual bases, and then to empirically analyse strategic governance and strategic management in the Czech Republic, where we will consider strategic management to be one of the attributes of strategic governance. The subject of the research is to analyse the phenomenon of strategic governance and strategic management at the level of central government in the Czech Republic. It analyses the relationship between the government of the Czech Republic and the ideas of 'strategic governance' and 'strategic management' for the period 1989-2016, and seeks the

${ }^{1}$ František Ochrana, Michal Plaček and Milan Jan Po̊ček: Centre for Social and Economic Studies, Faculty of Social Sciences, Charles University, Email: ochrana@fsv.cuni.cz 
causes and factors causing the state of dysfunction within strategic governance and strategic management in the Czech Republic. The study aimed to: (a) investigate how the fall of the communist regime in Czechoslovakia (1989) developed the relationships of the Czechoslovak and Czech governments with the ideas of 'strategic governance' and 'strategic management'; (b) to analyse the current capacity of ministries in the Czech Republic for strategic governance and strategic management, and (c) based on the empirical research of policy workers in Czech ministries, to determine what proportion of time at work is devoted to conducting analytical, strategic, and forecasting activities. At the same time, we examined how the respondents viewed the need for 'strategic units' in the organizational structures of ministries.

The study was divided into several parts. Within the first part, the theoretical-conceptual framework was conceptualized. This was followed by a brief overview of the contemporary theoretical approaches and views on strategic governance and strategic management. For the purposes of our analysis, we attempted to formally define the logical relationship between the concepts of 'strategic governance' and 'strategic management' based on the existing debates. The second part of the study dealt with an analysis of strategic governance and strategic management in the Czech Republic. Research approaches and research methods were defined, and research questions were formulated. Models were then designed which could be used when examining the capacity for governance at the level of ministries in the Czech Republic. The third part presented the results of the study and the discussion regarding the same. Three distinct problems were dealt with: the root of the approach of the central governments of the Czech Republic to the idea of 'strategic governance' and 'strategic management', an empirical examination of the current organizational capacity for the performance of strategic governance and strategic management at the level of individual ministries of the Czech Republic, and an empirical analysis of the performance of the strategic activities of Czech ministerial employees in terms of the proportion of time staff spent engaged in the performance of analytical and strategic activities. The conclusion provided a synthesis of the findings and recommendations.

\section{STRATEGIC GOVERNANCE AND STRATEGIC MANAGEMENT (THEORETICAL AND CONCEPTUAL FRAMEWORK OF THE EXAMINATION)}

The starting point for examination of the issue of strategic governance is the concept of 'governance' (Osborne \& Gaebler, 1992; Pollitt \& Bouckaert, 2011; van Doeveren, 2011; Vymětal, 2008). Governance may be viewed from different perspectives. It may be examined from the perspective of policy-making, in terms of the role of institutions, or examined from the perspective of the achieved outcomes (Forbes \& Milliken, 1999; Ghosh \& John, 2005) which provide information on how the government is effective in execution of its activities. Regarding the quality of governance, effectiveness is dependent on the administration of public affairs. It therefore makes sense to seek an answer to the question of how to increase the quality of governance. The phenomenon of governance can also be examined in the light of differing characteristics (properties), such as the content, quality, condition, developmental perspectives, etc. In view of these characteristics we speak of 'species' (modes) of governance. One of them is 'strategic governance'. In the literature, we find various definitions of the term 'strategic governance', as well as different concepts and different approaches towards its exploration. For example, Dror $(2004)$ or Potůček et al. $(2007,2016)$ define strategic governance using a holistic approach when they compare a certain existing (current) state ('non-strategic governance') with the target state ('strategic governance'). Mulgan (2004) considers the following to be essential characteristics of the strategic governance: the existence of government strategies, existence of both short-term and long-term government objectives, formulated government visions and concepts, and to be systemic in the corporation of leading strategic ideas into the organisational structures of the government. Dror, moreover, considered being anticipatory an important feature of strategic governance, that is influencing the future for the better (2004). Montenegro and Bulgacov (2014) in the framework of governance, discuss governance networks and strategic outcomes. They also warn that 'strategic outcomes should not be limited to economic outcomes' (2014, p. 118). Another perspective is offered by de Vries \& Nemec (2013), who delivered a comprehensive assessment of economic and managerial government approaches formed on the basis of the ideas of New Public Management (NPM). Schuster, Smith, Corak \& Yamada (1994) combine strategic governance with strategic planning. The aforementioned brief review of literature dealing with the problem of governance, (i.e., strategic governance) shows that there are a variety of theoretical concepts and approaches to studying strategic governance. Their aggregate (but not complete) summary is shown in the Table 1 . 
Tab. 1: Approaches and views on the idea of 'strategic governance'

\begin{tabular}{|c|c|c|c|}
\hline $\begin{array}{l}\text { Approaches to the definition } \\
\text { of 'strategic governance' }\end{array}$ & $\begin{array}{l}\text { A key feature of the 'strategic } \\
\text { governance' }\end{array}$ & $\begin{array}{l}\text { Strengths and weaknesses of the } \\
\text { definition of 'strategic governance' }\end{array}$ & Representatives \\
\hline Holistic approach & New quality of governance & Holistic, but too general of a concept & $\begin{array}{l}\text { Potůček et al. (2007, } \\
\text { 2016) }\end{array}$ \\
\hline Anticipatory & $\begin{array}{l}\text { Concept of influencing future } \\
\text { for the better }\end{array}$ & $\begin{array}{l}\text { Directionality of strategic governance } \\
\text { for the future. 'Future' is conceived } \\
\text { rather declarative, without benchmarks } \\
\text { 'influencing the future for the better'. }\end{array}$ & Dror (2004) \\
\hline Actor-Network Theory & $\begin{array}{l}\text { Governance networks and } \\
\text { Strategic Outcomes }\end{array}$ & $\begin{array}{l}\text { Clarification of 'a labyrinth of } \\
\text { mechanisms and actors', neglecting other } \\
\text { characteristics of strategic governance }\end{array}$ & $\begin{array}{l}\text { Montenegro \& Bulgacov } \\
\text { (2014) }\end{array}$ \\
\hline 'Managerial' approach & $\begin{array}{l}\text { Management of changes, } \\
\text { linking governance and } \\
\text { performance }\end{array}$ & $\begin{array}{l}\text { Measurable results, but strategic } \\
\text { outcomes are examined only as economic } \\
\text { outcomes, respectively, the result of } \\
\text { effective management of the assessed } \\
\text { economic criteria }\end{array}$ & $\begin{array}{l}\text { Loorbach (2010); } \\
\text { Aristovnik \& Seljak } \\
\text { (2009); de Vries \& Nemec } \\
\text { (2013) }\end{array}$ \\
\hline Systemic structural approach & $\begin{array}{l}\text { Strategic governance as an } \\
\text { intersection of the dimension } \\
\text { 'strategic planning' and the } \\
\text { dimension 'government' }\end{array}$ & $\begin{array}{l}\text { A clear definition of the relationship } \\
\text { between 'governance' and 'strategic } \\
\text { planning'. Identifying the elements of } \\
\text { strategic governance, although rather } \\
\text { static view of the strategic governance. }\end{array}$ & $\begin{array}{l}\text { Mulgan (2004); Schuster, } \\
\text { Smith, Corak \&Yamada } \\
\text { (1994); Harris (2005) }\end{array}$ \\
\hline
\end{tabular}

Source: Authors

From a brief overview of the different approaches of governance, it is clear that in theory, there are a number of different theoretical considerations on the issue of governance. These views oscillate between the prevailing qualitative view and the quantitative approach to exploring strategic governance. At the same time, the individual authors and approaches differ regarding what is the key feature of strategic governance. This difference results from different approaches to strategic governance. Each approach, however, has its strengths and weaknesses. The advantage of a holistic approach is that it attempts to have a comprehensive view of the problem of 'governance'. On the other hand, however, this approach is too generic and descriptive, with the research focusing on the quality of governance. Other authors focus on one of the partial views, such as the economic, management, or structurally functional view of governance. Such a view is (logically) one-sided, however, as it is only focused on a specific aspect (strategic) of governance. An analysis of the literature also revealed that so far there has been no generally accepted concept of 'strategic governance', upon which it would be possible to rely during an analysis of strategic governance in the Czech Republic. Nevertheless, we may attempt a summary of the existing discourse on the concept of 'strategic governance'. 'Strategic governance' means the governance characterized by a persistent emphasis on the concept of 'influencing the future for the better' (Dror, 2004), and the anticipation of the future ability to effectively manage social processes (Ochrana et al., 2010). One of the prerequisites to achieve such governance is to use the tools of strategic management in the implementation of government policies (Governance, 2000; Potůček et al., 2007) and to promote efficiency in the public sector (de Vries \& Nemec, 2013).

For the purposes of analysis, in this study, it would be useful to further define specific features of 'strategic governance' that we followed during the empirical research of strategic governance and strategic management in the Czech Republic. This is in regards to specific features, where the given specific term ('strategic governance') differs from the specific concept ('governance'). To do this, we used a formal logical approach, which utilized the defining terms 'generic' and 'specific'. The formally logical relationship between the concepts of 'governance' (generic term) and 'strategic governance' (specific term) is shown in Figure 1. 
Fig. 1: The relationship between the terms 'governance' and 'strategic governance'

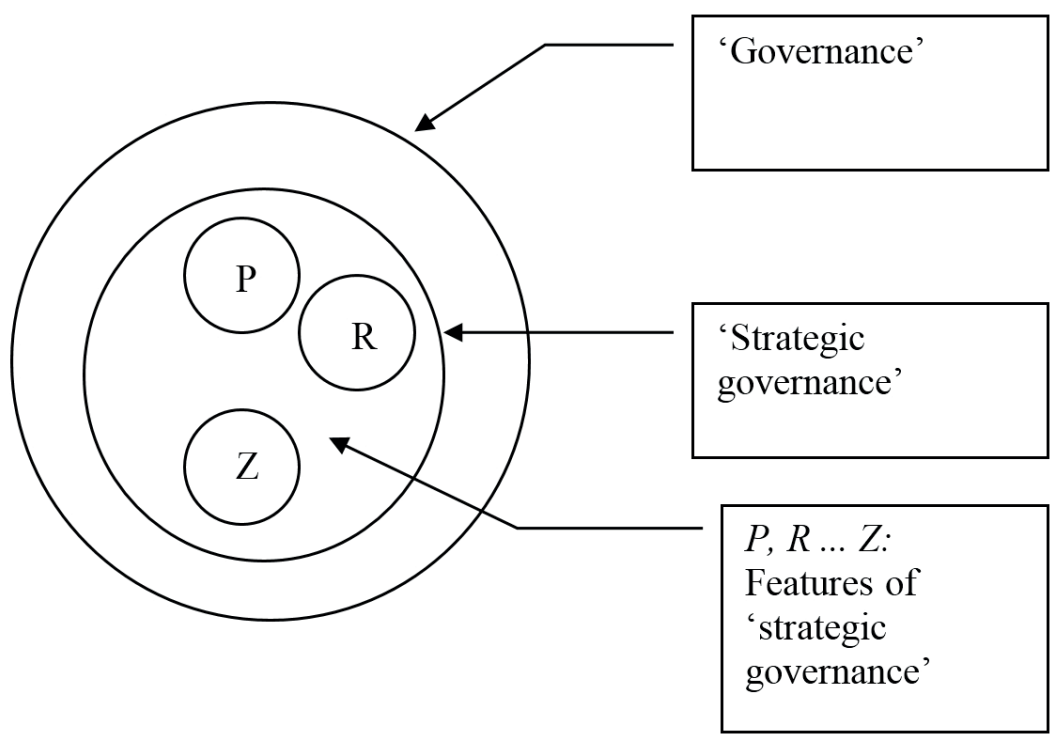

Source: Authors

We denoted the specific characteristics of 'strategic governance' by the letters $P, R \ldots Z$. These characters can be seen as attributes of strategic governance. The analysed theoretical model above (see Table 1) ordinarily names these characteristics (principles) of strategic governance: clear vision, strategy, strategic plans (their implementation and action plans) and strategic units.

Vision, strategic plans, strategies, and the implementation of plans usually exist in the form of government documents. Besides the aforementioned documents needed for the performance of strategic governance, some organizational elements (strategic units), which ideologically support strategic governance performance, are also needed for the performance of strategic governance. Their presence in the organisational structures of central administration authorities creates a potential (possibility) towards execution of strategic governance. In order to transform this possibility into reality, it is necessary that all formally existing 'strategic units' (e.g., sections, departments, etc.) at the central government level effectively perform this activity of 'strategic governing' and 'strategic managing'. The existence of strategic units, along with a clear mission, vision, strategic plan, forecast, etc., demonstrates the capacity to govern. Their presence (or absence) indicates the capacity for strategic governance and strategic direction of the company. In the next part of the study, we tried to answer the question - what is the status of strategic governance and strategic management in the Czech Republic.

\section{STRATEGIC GOVERNANCE IN THE CZECH REPUBLIC (RESEARCH APPROACHES, METHODS, AND RESEARCH QUESTIONS)}

In this part of the study, we examined the root of strategic governance and strategic management in the Czech Republic, and its communist past (Czechoslovakia). In order to explore the phenomenon of strategic governance in the Czech Republic, we used the genetic, 'static', 'dynamic' and comparative approaches. For an analysis of strategic governance capacities, we created several models in order to examine this. ${ }^{2}$ For an analysis of the capacities for strategic governance, we created several models which enabled

\footnotetext{
2 When applying genetic approaches, it will track how the idea of strategic governance was born and how it was (throughout the study period) realistically implemented. When we use the 'static' approach investigating the status of strategic governance, we find out what the actual capacity for the performance of strategic governance and strategic management at the surveyed institutions. 'Dynamic' approach allows us to analyze a particular time interval procedural changes in the development of strategic governance. Comparative approach compares the capacity for the performance of strategic governance between certain units being compared (i.e., countries, governments, ministries, etc.).
} 
Tab. 2: Distribution of properties (reference attributes) of the 'capacity to perform strategic governance' at the level of a single ministry

\begin{tabular}{llllll}
\hline Type of distribution $D_{i}$ & \multicolumn{4}{l}{ Reference attribute of strategic governance } \\
\cline { 2 - 6 } & $P$ & $R$ & $S$ & 0 & $\ldots$ \\
\hline$D_{1}$ & 0 & 0 & 0 & 0 & 0 \\
\hline$D_{2}$ & 1 & 0 & 0 & 0 & 0 \\
\hline$D_{3}$ & 1 & 1 & 0 & 0 & 0 \\
\hline$D_{4}$ & 1 & 1 & 1 & 0 \\
\hline$\cdots$ & & 1 & & 1 \\
\hline$D_{z}$ & 1 & 1 & 1 & 1 \\
\hline
\end{tabular}

Source: Authors

the examination of strategic governance capacity. The logic of the model was based on the assumption that we know the specific characteristics (attributes) of 'strategic governance', as shown in Figure 1. These include, in particular, the aforementioned vision, strategy, strategic plans, etc. We denoted 'all' characteristics of strategic governance by the letters $\mathrm{P}, \mathrm{R}, \mathrm{S}, \mathrm{Q}$...Z. The model then took the form of the following matrix (Table 1$)$. The column 'type of distribution' $\left(\mathrm{D}_{1} \ldots \mathrm{D}_{\mathrm{Z}}\right)$ reflects how the distribution of characters $P$, $R, S, Q \ldots Z$ was within a reporting entity (e.g., a ministry). The reference attributes $P, R, S, Q \ldots Z$ testified to the capacity to perform strategic governance. We then devised a model for the case where we examined the capacity to perform strategic governance at the level of a single ministry. Formalised outputs of such an empirical analysis were compiled into the following matrix (Table 2).

We determined any presence of the given feature through empirical examination with regard to the content of the reference attribute $P, R, S, Q . . Z$. Reference attributes (feature components) of strategic governance $P, R, S$, $Q$, etc. are such characteristics that described the strategic governance and strategic management. At the level of ministries these may be, for example, relevant documents (visions, strategies, forecasts and concepts) and indicators of practical exercise of strategic governance and strategic management. Research results were, in turn, assembled into a table using a binary code. The real presence of the given component attribute was indicated by the binary code 1 , while its absence corresponded with the binary code 0 . The distribution type $D_{i}$ gave evidence of the quality of the 'capacity to perform strategic governance'. Thus, for example, the distribution $D_{I}$ represents the case where none of the reference attributes characterising strategic governance was present (satisfied). The resulting degree of the 'capacity to perform strategic governance' was therefore nil. For such a subject, we could confidently state that towards the exercise of its power, it absolutely did not adopt tools of strategic governance. A contrary case was represented by the distribution $D_{z}$, where the given actor exhibited an ideal 'capacity to perform strategic governance' in terms of the monitored component features (exhibited reference attributes). In all the reference attributes, it scored the value of one. The presented model was a supporting tool for an internal audit of individual ministries. Top ministerial representatives may use it as a tool to obtain feedback on what capacity the given ministry possesses towards performing strategic governance within the given type of public policy. We could apply an analogical procedure also when testing the capacity to perform strategic governance at the level of the entire government (respectively, at the level of multiple selected ministries).

The presented model can also be further modified. It can be used to investigate changes in strategic governance capacities within a certain time interval $T_{1} \ldots T_{n}$. This can be managed both at the level of ministries and for comparisons at the level of multiple ministries. In this part of the study, we present a proposed model devised to compare changes at the given ministry with respect to its capacity to pursue strategic governance in time. When implementing the model, we proceed as follows: first, we set the reference period for which we shall compare changes that have occurred in the domain of the capacity to perform strategic governance. The given points in time $T_{1} \ldots T_{n}$ are usually selected so as to match certain time check points when, for example, how a certain concept or adopted strategy being implemented within a given ministry is being checked out. At the same time, we choose the reference attributes whose distribution will serve as the basis against which we will compare any potential changes. Let us denote the reference attributes as $P, R, S, Q \ldots Z$. For these attributes, we check whether there were substantial changes over time in the content. Changes are recorded in a prepared Table 3. 
Tab. 3: Distribution of reference attributes of the 'capacity to perform strategic governance' in time at the level of a single ministry

\begin{tabular}{lllllll}
\hline Point in time & \multicolumn{3}{l}{ Reference attribute } & & & \\
\cline { 2 - 6 } & $P$ & $R$ & & & & \\
\hline$T_{i}$ & & & & & \\
\hline$T_{2}$ & & & & & \\
\hline.. & & & & & \\
\hline$T_{n}$ & & & & \\
\hline
\end{tabular}

Source: Authors

Tab. 4: Distribution of reference attributes of the 'capacity to perform strategic governance' at the level of individual ministries within the time period $T_{1} \ldots T_{n}$

\begin{tabular}{llll}
\hline Ministry & \multicolumn{4}{l}{ Distribution of monitored attributes $P, R, S, Q \ldots Z$ at the given point in time $T_{i}$ Commentary } \\
\cline { 2 - 4 } & $T_{1}$ & $T_{2}$ & $T_{n}$ \\
\hline$M_{1}$ & $P, R$ & $P, R, S$ & $P, R, S, Q \ldots Z$ \\
\hline$M_{2}$ & $P, R, S, Q$ & $P, R, S, Q \ldots Z$ & $P, R, S, Q \ldots Z$ \\
\hline$\ldots$ & $\ldots$ & $\ldots$ & $\ldots$ \\
\hline$M_{n}$ & $\ldots$ & $\ldots$ & $\ldots$ \\
\hline
\end{tabular}

Source: Authors

Based on the changes in these indicators, we may observe what qualitative and quantitative changes will occur over time in the domain of the capacity to perform strategic governance. The given table (matrix) provides relevant information indicative of changes in the capacity of the given authority (ministry) to perform strategic governance. The collected information may in turn be used by the top ministerial representatives for the purposes of internal strategic audits.

This ('dynamic') model can be modified in the event that they want to compare changes in the capacity for governance at the level of all ministries (at the level of government) - see Table 4. Comparative analysis of the capacity to perform strategic governance in time may be carried out across the whole government (or possibly across selected ministries) as well. The proposed model may be used as a supporting instrument for a strategic audit of the Czech Republic. The results of such an analysis may form part of the performance audit of governments (or a part of the performance audit of ministries, respectively) and stand as a source of information for draft reform changes.

When implementing the model, we proceed so that after specifying the set of monitored ministries and the characteristics (properties) that testify to the capacity to perform strategic governance, we subsequently examine at individual points in time $T_{1} \ldots$ $T_{n}$ at each point $T_{i}$ the presence of the given reference attributes. We start with the examination at time $T_{l}$. This period describes the initial state. In the commentary, we record the qualitative and quantitative characteristics of the examined attribute $P . . Z$. Also, in the commentary, we state what reference characteristics are missing and identify the reasons for their absence. At the same time, we analyse the negative impacts of the missing properties and give recommendations towards their remedy. At the following time, $T_{2}$, we examine what modifications took place over this period and describe the (qualitative and quantitative) changes in the commentary section (audit report). In our chosen illustrative example, the characteristics $S, Q \ldots Z$ (e.g., missing implementation plans $S$, tools $Q$ towards the support of strategic decision-making are not being applied, and strategic documents $Z$ are also missing) are absent for the ministry $M_{1}$ in time $T_{1}$. The minister in turn takes relevant remedy measures. As is evident, within the audit in time $T_{2}$, the implementation documents $S$ are no longer missing, but the tools $Q$ towards support of strategic decision-making have still not been 
Tab. 5: Comparison of signs of strategic governance and strategic management at the level of individual ministries

\begin{tabular}{llllll}
\hline Ministry & \multicolumn{5}{l}{ Reference attribute of strategic governance and strategic management } \\
\cline { 2 - 6 } & $P$ & $R$ & $S$ & 0 & Z \\
\hline$M_{1}$ & 0 & 0 & 0 & 0 & 0 \\
\hline$M_{2}$ & 1 & 0 & 0 & 0 & 0 \\
\hline$M_{3}$ & 1 & 1 & 0 & 1 & 0 \\
\hline$M_{4}$ & 1 & 1 & 1 & & 0 \\
\hline$\ldots$ & & & & 1 & 1 \\
\hline$M_{z}$ & 1 & 1 & 1 & \\
\hline
\end{tabular}

Source: Authors

implemented, and the documentation $Z$ is also still missing. At time $T_{3}$ the situation has already been rectified in full. The given ministry $M_{l}$ finally shows the full capacity to pursue strategic governance in terms of the prepared documentation. The usefulness of the proposed temporal model is in that the time analysis of the distribution of attributes, indicative of the capacity to pursue strategic governance in time $T_{1} \ldots T_{n}$, allows for the making of comparisons among individual ministries and to inquire whether the desirable changes took place over time. The above mentioned models can be used as support tools for the empirical examination of strategic governance and strategic management. The proposed models can be ad hoc edited. In our subsequent empirical analysis, we have modified one of the models (Table 4) into a version, which can be seen in Table 5 .

For comparison of the capacities for strategic governance and strategic management at the level of individual ministries, we have selected the aforementioned characteristics (indicators) of strategic governance $P$... $Z$. The proposed model can be universally used (for different countries and for different levels of strategic governance) when examining the phenomenon of strategic governance. Of course, we are aware of a certain weakness in the proposed model, which lies in the fact that the choice of characters $P$... $Z$ is to a certain extent arbitrary. However, in our opinion, the proposed model enables the comparison of the existing 'system status' of the contrasted entities. In our particular case, we will be following these characters at individual ministries of the Czech Republic: vision, strategy, forecast, concept (conception) and real existence (absence) of element in the organizational structure dealing with strategic management and strategic planning at the ministry. A selection of these features influenced, in particular, the following studies: Corak \& Yamada (1994), Dror (2004), Harris (2005), Potucek et al., (2007, 2016). Our proposed descriptive model uses binary codes 1,0 , which means that it shows the presence of a given character (binary 1 ) or its absence (binary 0 ). A table (matrix) then gives the resulting picture of the state of strategic governance and strategic management at the level of the compared ministries. An edited modification of the model is used in the next study to investigate the capacity of ministries of the Czech Republic for the implementation of strategic governance and strategic management.

\section{Research questions}

In the study, we asked the following questions:

1. What changes did the idea of 'of strategic governance' and 'strategic management' undergo in Czechoslovakia and in the Czech Republic after 1989 ?

2. What is the current organizational capacity for the performance of strategic management and strategic planning in individual ministries of the Czech Republic and what conclusions arise from the findings?

3. What part of working time do officials within the ministries (policy workers) dedicate to the performance of strategic activities? 
In seeking answers to the above questions, an analysis of strategic documents from individual ministries of the Czech Republic was conducted. The documents were obtained partly in connection with the long term work of expert authors of the study of activities in ministries, and were also obtained from the websites of ministries. Further information (to find the answers to the second and also the third research questions) was obtained from seven interviews (February-April 2016) with employees from the Ministry of Defence, Ministry of Interior, Ministry of Health, Ministry of Finance, Ministry of Agriculture and Ministry for Regional Development. Sound recordings were made of these interviews. One interview (Ministry for Regional Development) was conducted, at the request of the respondent, without being recorded. In all cases, the respondents were working in positions as policy workers and decision makers.

The answer to the third question was based on our own additional empirical research, which was carried out in the framework of the research project Czech Science Foundation Nr. 0404 / 12/725, 'Policy Workers in the Czech Public Administration: Practices, Professional Values and Identity' (see Veselý, 2013).) The research was conducted over the period April to June 2013. All 14 ministries of the Czech Republic as specified within the Act No. 2/1969 Coll., on the establishment of ministries and other central government bodies of public administration, as amended (as of 30 April, 2013) were addressed. Three ministries opted not to participate in the research (the Ministry of the Interior, the Ministry of Regional Development and the Ministry of Agriculture). The basis for the selection of the respondents formed a list of potential respondents that, according to the research team's specifications were provided by the individual ministries. The respondents were selected randomly. Through a series of random selections, all (or almost all) entities included in the database of individual ministries were addressed. The random selection, thus, virtually became an exhaustive selection. The questioning took place using the following forms: for eight ministries through personal interviewing (F2F, face-to-face) using a questionnaire with precisely specified questions, either paper-based (the so-called CAPI) or assisted by a laptop (the so-called PAPI). For two ministries, the interviewing was conducted through the filling in of an online questionnaire (the so-called CAWI) without the participation of interviewer, as the so-called 'emergency' form for the cases when it was not possible to utilise the F2F form. In one case, a combination of both methods (F2F and CAWI) was adopted. A total of 4,600 respondents were reached, while a total of 1,351 respondents answered. Most questionnaires were filled out using the PAPI method (992 questionnaires), 124 questionnaires were answered using the CAPI form and 235 questionnaires were completed using the CAWI method. For more information about the research, see Veselý (2013).

\section{RESULTS OF EXAMINING THE DEBATE}

\section{The Genesis of strategic governance in the CR since 1989 - now}

The fall of the communist regime in Czechoslovakia started a range of regulatory reform changes. It would seem that the return to multi-party democracy would lead the Czech Republic towards the cultivation of governance in the style of Western European democracy. In fact, with regard to the idea of 'strategic governance', quite the opposite occurred (see Potůčck et al., 2011). ${ }^{3}$ What was the cause of this situation? With the collapse of centrally planned and controlled society, following the anti-communist coup in 1989, an aversion to everything that (even formally) resembled the idea of central planning was formed. Thus was born (at the time quite understandable) a resistance to anything that even formally resembled residues of the previous regime. Following November 1989, the ruling elite had become liberal economists who relied on the 'omnipotence of the invisible hand of the market'. They assumed within post-November governments of 1990s, the key posts (e.g., Finance Minister and Prime Minister Klaus, Deputy Prime Minister Dlouhý, Ministers Dyba, Kočárník, Zieleniec and Ježek), although many of them were under the communist regime nomenclature cadres of the Communist Party of Czechoslovakia (herein after KSČ) and members of the pre-November KSČ.

The liberal course had quite easily won the political competition on how to govern. That is to say, it had (unlike other political movements) a relatively "clear" idea of how to rule in post-communist Czechoslovakia. The ideological approach was modelled on the works of Hayek (1944, 1973 and 1979). The promoters of liberalism in Czechoslovakia, soon after the anti-communist coup,

3 In addition to these sources, there is no other literature that would address this issue. The personal experience of the authors of the study with work within the ministries of the Czech Republic (deputy minister, policy worker and policy maker of the ministry) was therefore used. Also, as mentioned, the knowledge from expert work in the ministries and informal interviews with witnesses and experts to the problem was also used (Potůček, Petrášek, Prikryl). 
intensely translated this as the role model for building capitalism. The new government representatives relied upon the spontaneity of social development and the self-regulation of the market. Therefore, they preferred a strategy before tactics, of solving everyday problems before setting and addressing the issues of the future improvisation before conception. The idea of 'strategic governance' was conceived as the 'residue of the centralist era' and pushed out by political improvisation. Despite the fact that within the postcommunist politics, a group of politicians from the Forecasting Institute (later Prime Minister Zeman, Deputy Prime Minister Komárek) was present. This group was in the minority and unable to practically enforce the idea of 'strategic governance' in the Czech politics. As noted by the leading experts on strategic governance in the Czech Republic, Potůček and Přikryl (in Potůček et al., 2007), this led to the fact that conditions for enforcing and implementing strategic governance were highly unfavourable immediately after 1989. This is also confirmed by the subsequent development in Czechoslovakia after 1989, by the development of governmental policy after 1993 when the Czechoslovak federation disintegrated. Under these circumstances, it therefore is not surprising that in June 1990, the State Planning Commission, which assumed the role of the central planning institution of centralised planning in socialist Czechoslovakia, was abolished. It was replaced by the Federal Ministry for Economic Strategy. This ministry was established as the central authority of state administration of the Czech and Slovak Federal Republic for addressing conceptual issues of longterm strategy for economic and social development. Within a month (in July 1990), this ministry was transformed into the Federal Ministry for Strategic Planning. Its jurisdiction was within the amendment to the Competence Act, ${ }^{4}$ Section 19, defined as follows: 'The Federal Ministry for Strategic Planning is a central government authority of the Czech and Slovak Federal Republic for longterm strategy for economic and social development' and its task was to develop proposals for the support of strategic governance in all relevant areas. However, the Ministry did not manage to realize the established activities of strategic planning.

In the political atmosphere of ruling liberalism, it is not surprising that in October 1991, the dissolution of the Federal Ministry for Strategic Planning was decided upon. The tasks of this ministry were formally entrusted to the jurisdiction of the Federal Ministry of Economy and to the Deputy Prime Minister. By the end of 1992, the Ministry had ceased to exist and with it also the only central state institution, which had in its name the term 'strategic planning. Following the break-up of the Czechoslovak Federation, there came a steep onset of liberalism led by the Prime Minister of the Czech Republic, Václav Klaus. The liberal conception of politics had won, and within its scope there was 'logically' no place for strategic reasoning. It was expected that resolving the economic transformation would automatically lead to a transformation of the whole society. This corresponded with the logic of liberalistic view of a society. Economists who assumed key posts in governing the society relied on their one-sided economic view regarding spontaneous problem-solving. Such a method of governance did not need any institutions producing ideas of strategic governance. Then a period of an 'institutional vacuum' arrived where there was no institution which should, within its jurisdiction, produce ideas supporting the strategic governance in the Czech Republic (Potůček et al., 2007, 2011).

Over the following period (1998-2002), there was a hint of a change in the approach of the ruling elites towards strategic governance. This change is associated with the social democratic Prime Minister (prognosticator) Zeman. Under his government, a consultative governmental body called 'the Council of the Government of the Czech Republic for Social and Economic Strategy' (hereinafter the Council) was established in 1999 as an advisory, coordinating and initiating body of the government for the domain of strategy for social and economic development of the Czech Republic. The purpose of the Council was to generate forecasting and analytical ideas as an information support to the government's strategic decision-making and strategic management. The most important outputs of the Council became two Medium-Term Concepts of Social and Economic Development of the Czech Republic (2001, 2002), which the government had taken note of. The Council had also organised a series of seminars on the issue of social and economic development. The Council had all the typical features (strengths and weaknesses) characteristic to advisory bodies. In short: it could advise, but its conclusions were not binding on the government. Potůček and Přikryl deal with an assessment of the Council's activities in their publication 'Strategic Governance and the Czech Republic' (Potǔček et al., 2007, pp. 129-130). They note three main tasks needed to design legislative norms of the system of strategic management, processing long-term visions of socio-economic development of the Czech society, and methodological guidance and content-coordination of processing mediumterm concepts and their realization. The first task - to draft the legislation on strategic planning - had failed. The government called it a premature step. In this context, it is worth noting that, although such an act was not adopted, it was still far from being a fatal factor for the execution of strategic planning. This can be done institutionally in a way that the government implements strategic

4 Act no. 2/1969 Coll. Act of the Czech National Council of 8 January1969, on the establishment of ministries and other central government authoritiesof the Czech Republic, as amended. 
governance and individual ministries have strategic planning and management in their jurisdictions, which they practically carry out. Although the government adopted a resolution towards processing the 'Strategic Programme of Social and Economic Development of the Czech Republic' in 1999, it approved the work schedule 'National Vision of the Development of the Czech Republic in 2000' and adopted a working timetable for the 'Medium-Term Coordination of Ministerial Concepts in 2000', the respective tasks were not adequately accomplished. It seems that the root cause was a mismatch between the supply from the Council (vision) and the demand from individual ministries for a practically-oriented document that would become an information source for initiating the work on ministerial concepts. This discrepancy was, by some ministries, seen as a failure in the Council's functionality. However, the Council, in fact, possessed too little capacity to methodologically support ministries in the formation of concepts. This fact was used as a criticism on the part of ministries who asked whether such a work place is under given circumstances necessary. In 2002, the Council was abolished, and in 2003, the Governmental Council for Sustainable Development (RVUR) was established. Although this institution formally retained the domain of strategic governance, the issues of strategic governance were reduced solely to the domain of sustainable development strategy. An institution that would comprehensively address the issue of strategic governance (Potůček et al., 2007, 2011) still persists in its absence.

To the extent that one can talk about some elements of the strategic thinking of governments, it is possible (after 2003) to spot them within the participatory approach towards the composition of documents. For example, the Strategy for Sustainable Development or the National Action Plan for Social Inclusion 2004-2006 was compiled under the coordination of the Ministry of Labour and Social Affairs. In 2007, a resolution was adopted by the government; it was the document, 'Effective Public Administration and Friendly Public Services' with the subtitle 'Smart Administration Strategy for the Period 2007-2015' (MV 2007). Also, the document 'Methodology for Preparation of Public Policies (2013)' (MMR 2013) was also adopted and prepared in co-operation with representatives of the individual ministries, the Office of the Government, the Association of Regions of the Czech Republic, the Union of Towns and Municipalities of the Czech Republic, and the Czech statistical Office. In fact, this document is a typical example of an 'edentulous' (non-binding) document which obliges no one to carry out strategic activities. In the introduction to this document, it is stated: 'The methodology is, with regard to strategic work, intended for the creation of a strategy, while it is not intended for activities that precede the formulation of a strategy and neither for the follow-up activities.' (Methodology of preparation of public policies: 2013, p. 3).

Although various concepts are processed at some ministries, these, nevertheless, exist as mostly 'isolated' documents without any links to the (missing) global societal visions, strategies, and concepts that would be centrally coordinated and based on a comprehensive, fundamental government document. This dismal situation is also due to the fact that, in the Czech Republic, an element in the governmental authorities which would deal with strategic governance is still lacking. We may therefore conclude that the Czech Republic does not, at the central government level, have any independent institution that would generate ideas towards strategic governance and coordinate its practical implementation. Governments of the Czech Republic are not supported by (and even do not demand any) ideas of strategic governance within the execution of their activities. And how is the situation at the individual ministries? We attempt to answer this question within the following section of the paper. We examine the capacity towards strategic governance from the perspective of two reference attributes - organisational structures to pursue strategic governance and the existence of governmental documents to support the execution of strategic governance. To do this, we have proposed a model of determination of the capacity to perform strategic governance at the level of a given ministry or ministries.

\section{The current organizational capacity for the performance of strategic governance and strategic management at the level of individual ministries}

In this part of the study, we applied the model (see Table 4) to compare the capacity to perform strategic governance at the level of all the ministries. We examined the real organizational structure of the individual ministries and the Act no. 2 / 1969 Coll., on the establishment of ministries and other central Government Authorities of the Czech Republic. The aim of this analysis was to determine what kinds of organizational potential individual ministries of the Czech Republic possess to perform strategic governance and strategic management. The given approach allowed the determination of whether the examined ministry had components that allowed for elaborating the relevant strategies, concepts, outlook policies, etc. in the context of the idea of 'strategic governance' (see Dror, 2004; Potůčck (. 2004) and 'strategic management' (Wright \& Nemec, eds., 2002; Ochrana et al., 2010) in its organisational 
structure or specified jurisdiction (activities). ${ }^{5}$ The results of our examination are shown in Table 5. Binary code (1.0) in the column 'organisational component within the structure bearing the name "strategic" provides information as to whether a component with the given name is in the organizational structure of the Ministry. Other columns labelled by the terms 'vision', 'strategy', 'forecast', 'concepts' indicate information (binary code 1.0) as to whether the Act no. 2/1969 Coll., 'On the competence of central government authorities in individual ministries' explicitly defines an obligation to perform these activities. Therefore, in our model, we have not examined whether these products (vision, strategy, etc.) contain other components.

The research results revealed some interesting findings. As is evident from the table, only eight ministries have a component explicitly called 'strategic' in their organisational structures. This obviously does not have to mean that other ministries necessarily do not perform any strategic activity. It may, in fact, be 'hidden' under activities of other organisational components. Therefore, we conducted an examination of jurisdictions (activities) of individual ministries as specified by the Competence Act, and through it derived jurisdictions of the ministerial organisational structures. The analysis showed that most of the ministries of the Czech Republic have assigned tasks (activities) related to strategic governance ${ }^{6}$ in their jurisdictions.

The analysis of organizational structures of the ministries of the Czech Republic revealed that no ministries (or the Czech government as a collegial body) within their structures have so-called strategic units, as is common in the developed European countries as reported by Potůček et al. (2007). Czech ministerial employees themselves, who are in the positions of policy workers, agree that such work would need to be established within the ministries. This is confirmed by the results of our empirical research (interviews) conducted in the months of February to April 2016 with policy workers in the ministries of the Czech Republic. All respondents agreed that for the effective performance of strategic governance, it is necessary to create a component (strategic unit) that will generate ideas to support the strategic management at their respective ministries. Respondent A (Ministry of Health) defined that need as follows: 'I think it should be internalized within each ministry ... it should be a stable department or department accounting for enough people relatively' (interview with Respondent A, April 4 2016). Respondent B also expresses the same need from the Ministry of Agriculture.

We note that while the ministry is specific in itself, it has in its structure (or subordinated) about 15 scientific research institutes. Nevertheless, the respondent from the Ministry of Agriculture sees the need to create a workplace of 'strategic units'. Respondent B answers: 'Yes, I think that would be sensible to create such an element' (interview with respondent B, March 31, 2016). Respondent C (Ministry of Defence) sees the point of such work in that, it generates new ideas and at the same time would help to 'pass into the everyday practice' (interview with the respondent C, April 16, 2016). Respondent D (Ministry of Finance) sees a key role for 'strategic units' in the transfer of scientific findings into practice (interview with respondent D, May 5, 2016). We can thus conclude that policy on the part of workers demands the need to develop a ministerial department of 'strategic units'. In the context of the experience of other European countries, which has been generalized in the scientific literature, regarding the problem strategic governance (Harris, 2005; Potůčk et al., 2007; Schuster et al. 1994) and strategic management (e.g., Bouckaert et al., 2009; Johnson et al., 2007 ; Protecting et al., 2010; Visser, 2016,), such a provision department at the government level or at the level of the individual ministries (along with the implementation of strategic management) can be considered as one of the factors that can improve the level of strategic governance and strategic management in the Czech Republic.

5 Activities (i.e., jurisdiction) of the ministries in the Czech Republic are determined by the Act no. 2/1969 Coll., on the establishment of ministries and other central government authorities of the Czech Republic, as amended.

6 It is probably the result of unsystematic interventions of politicians into the amendment of the Competence Act and the already mentioned 'aversion' of legislators towards the idea of strategic governance. The Competence Act was adopted in 1969. Prior to the political take over (November 1989), the Act had been amended in total eight times. After 1989, over a hundred of amendments were carried out. Interventions were often purpose-targeted. Politicians often use the setting up and tearing down of ministries to meet their partial political objectives. Their interventions into legislation are often amateurish. This is also evidenced by the case of a debate over the Act on Public Service (autumn of 2014), when incompetent interventions by politicians into this Act that were made; even after the relevant discussion was concluded, they have introduced into the Act a reference to an already cancelled (non-existent) component, mentioned in the previous version of the bill. The President vetoed the bill and submitted an application to the Constitutional Court. Among the Czech public circulates on the legal education of politicians (MPs) a "fitting joke" that these politicians (graduates of the University of West Bohemia in Pilsen) have not seen the law school even from a tram. (The Faculty of Law in Pilsen is 'famous' for its non-standard modes of study of some of its graduates - including current MPs - through various scandals, for example, the fact that it was possible to graduate from it through opting for an extramural form of study within a couple of months and to earn the doctorate degree in law (JUDr.) under odd circumstances. 
Tab.6: Audit results of the analysis of activities (jurisdiction) and ministerial organisational structures with regard to the performance of strategic governance

\begin{tabular}{|c|c|c|c|c|c|c|}
\hline \multirow[t]{2}{*}{ Ministry } & \multicolumn{4}{|c|}{$\begin{array}{l}\text { Explicitly defined jurisdiction specified by the } \\
\text { Competence Act within the domain of }\end{array}$} & \multirow{2}{*}{$\begin{array}{l}\text { Organisational } \\
\text { component within the } \\
\text { structure bearing the } \\
\text { name "strategic" }\end{array}$} & \multirow[t]{2}{*}{ Comment } \\
\hline & Vision & Strategy & Forecast & Concept & & \\
\hline Ministry of Finance & o & 0 & 0 & 0 & o & $\begin{array}{l}\text { There are analytical } \\
\text { departments }\end{array}$ \\
\hline Ministry of Foreign Affairs & o & o & 0 & 1 & 1 & $\begin{array}{l}\text { Office of strategy, analyses } \\
\text { and project management; } \\
\text { department of consular } \\
\text { concepts }\end{array}$ \\
\hline $\begin{array}{l}\text { Ministry of Education, Youth } \\
\text { and Sports }\end{array}$ & o & o & 0 & 0 & 0 & $\begin{array}{l}\text { There is a methodology- } \\
\text { analytical section }\end{array}$ \\
\hline Ministry of Culture & o & o & 0 & 0 & 0 & $\begin{array}{l}\text { Unit of cultural policy and } \\
\text { concepts }\end{array}$ \\
\hline $\begin{array}{l}\text { Ministry of Labour and } \\
\text { Social Affairs }\end{array}$ & o & 0 & o & 0 & 0 & $\begin{array}{l}\text { In each section, there is a } \\
\text { conceptual component }\end{array}$ \\
\hline Ministry of Health & o & 0 & 0 & 0 & 0 & Unit of science and research \\
\hline Ministry of Justice & o & o & o & o & o & $\begin{array}{l}\text { Decomposition of sections is } \\
\text { not available }\end{array}$ \\
\hline Ministry of Interior & o & 0 & 0 & 0 & 0 & $\begin{array}{l}\text { Department of conception } \\
\text { and coordination IS }\end{array}$ \\
\hline $\begin{array}{l}\text { Ministry of Industry and } \\
\text { Trade }\end{array}$ & o & 0 & o & o & 1 & $\begin{array}{l}\text { Section of strategy and } \\
\text { economy of industry }\end{array}$ \\
\hline $\begin{array}{l}\text { Ministry of Regional } \\
\text { Development }\end{array}$ & o & 0 & 0 & 0 & 1 & $\begin{array}{l}\text { Department of strategy } \\
\text { and policy coordination; } \\
\text { department of development } \\
\text { and strategy of regional } \\
\text { policy }\end{array}$ \\
\hline Ministry of Agriculture & o & 0 & o & o & o & $\begin{array}{l}\text { Department of conceptions, } \\
\text { department of research and } \\
\text { development }\end{array}$ \\
\hline Ministry of Defence & o & 0 & 0 & 1 & 1 & $\begin{array}{l}\text { Section of defence policy } \\
\text { and strategy }\end{array}$ \\
\hline Ministry of Transport & o & o & 0 & 0 & 1 & $\begin{array}{l}\text { Department of emergency } \\
\text { planning and defence } \\
\text { planning }\end{array}$ \\
\hline Ministry of Environment & o & o & 0 & 0 & 1 & $\begin{array}{l}\text { Unit of strategies; Unit } \\
\text { of conceptions; unit of } \\
\text { monitoring and planning }\end{array}$ \\
\hline
\end{tabular}

Note: $1-$ yes; $0-$ no.

Source: Act no. 2/1969 Coll., on the establishment of ministries and other central government authorities of the Czech Republic, as amended. Own research. 


\section{Empirical Analysis of the performance of strategic activities of employees (policy workers) within the ministries of the Czech Republic}

The efficiency of performance of strategic management at the ministerial level will depend, to a significant extent, on the activities of the policy workers. Their examination was addressed by Colebatch et al. (2010), Evans et al. (2011), Evans \& Wellstead (2013) and Howlett $(2009,2011)$. In the Czech Republic (and also in the countries of Central and Eastern Europe), this problem is currently being neglected. An exception is the recently published study by Czech authors Veselý (2014) or Veselý et al. (2014) and the study by Nekola \& Kohoutek (2016), which was devoted, however, to the issue of the government (regions). Their analysis is based on an empirical investigation carried out in the framework of a research project of the Czech Science Foundation Nr. 0404 / 12/725, 'Policy Workers in the Czech Public Administration: Practices, Professional Values and Identity'. The research subject was an analysis of a profile of those employees of public administration who perform activities typical for policy workers. These are predominantly ministerial staff, organisationally integrated into relevant strategic, analytical or conceptual sections, divisions or departments. Those ministerial employees who the perform so-called administrative-support activities, in particular maintenance, executive logistics, running of secretariats, provision of support information services and general organisationally-administrative activities into the research, were thus not included. For all the surveyed ministerial employees, who are responsible for the performance of strategic, analytical and conceptual activities that we consider important characteristics of strategic governance and strategic management, deficiencies in the performance of strategic activities were identified. If we take the case of implementation of suddenly emergent (socalled operational) tasks, for which we have in our research coined the term 'putting out fires versus strategic activities' as a contrary case to the performance of strategic activities, the research results were as follows: $8 \%$ of the respondents stated that 'putting out fires' ('fire-fighting activities') occupies more than $50 \%$ of their working time; a further $28 \%$ stated that 'putting out fires' represents one fifth to one half of their working time. This means that ministerial employees, who should focus on strategic activities, have only a limited time capacity to deal with them. The consequence is that our respondents stated they devote only a very limited amount of time to activities possibly described as 'strategic activities' (exceeding a year-long time horizon), as shown in Table 7.

As is evident, the professional ministerial employees, who work in the positions of analytical and conceptual workers, engage very little in strategic activities. Where is the problem? Is it the result of deficiencies in the organisation of work, ministerial management, or incompetent ministerial leadership on the part of political leaders? It seems that the culprits are mostly politicians (ministers, deputies) who initiate the shortfall in strategic management of ministries. In the case of the Czech Republic, it is no exception that some ministers and their deputies do not possess even minimum professional requirements (skills) for running ministries. This leads to conflicts between the political leadership of the given ministry and its expert management. All this adversely affects efficiency of the governance's performance. Governments of the Czech Republic, in most cases, do not feel the need to strategically govern and strategically manage, nor do they suffer from the shortfall of effective governing. We encountered a similar situation in other CEE

Tab. 7: Estimated share of working time of respondents devoted to strategic activities (average for all ministries)

\begin{tabular}{ll}
\hline Number of respondents (\%) & $\begin{array}{l}\text { Estimated share of the working time } \\
\text { devoted to strategic activities (\%) }\end{array}$ \\
\hline 4 & 51 and more \\
\hline 15 & $21-50$ \\
\hline 58 & $1-20$ \\
\hline 24 & 0 \\
\hline
\end{tabular}

Source: Own research - Czech Science Foundation No. O404/12/725, 'Policy Workers in the Czech Public Administration: Practices, Professional Values and Identity'.

7 The methodology of this research, along with a detailed description of the research sample is dealt with by the study of Vesely (2013). A. Veselý was head of the project mentioned. 
countries as well, as shown by Bouckaert et al. (2009), Coombes \& Verheijen (1997), Nemec (2010), Rosenbaum, Nemec et al. (2006), Schimmelfennig \& Sedelmeier (2004) and Dunn, Staroňová \& Pushkarev (2006). The mentioned authors point out that in these countries, not only are prerequisites for strategic governance and management lacking, but also the ability to implement strategic objectives of government policies.

The shortfall of effective governance (or strategic governance, respectively) may be induced by various causes. These may include, for example, dysfunctions in activities of the institutions (Immergut, 1998), inadequate behaviour of actors of public policies (see Potůček, 2016; Niskanen, 1998) or formations of their coalitions (Sabatier et al., 1999; Sabatier \& Weible, 2007; Novotný \& Nekola, 2010), where the given coalition partners apriori reject the idea of 'strategic governance'. Another cause may be a failure in the domain of participation, namely direct or indirect participation of citizens in the administration of public affairs, respectively their voluntary activity in solving issues of public policies. With the fall of communist regimes in the Central and Eastern Europe, the participative approach has become a part of public administration reforms (see e.g. Wright \& Nemec, eds., 2002). We may distinguish three different approaches of political representation regarding public involvement in decision-making processes: passive, selectively-active and accommodating (participative). Within the passive approach, a citizen is conceived as a passive addressee of government decisions. It is an approach in which the authority of public administration 'paternalistically' decides on behalf of its citizens. Within the selectively-active approach, the public is engaged in communication on the given issue in an ad hoc manner (i.e., selectively). Examples include discussions on public projects (construction of highways, bypasses, etc.) which cause negative externalities. The participative approach leads to a permanent flow of information between public administration authorities and the public. Both actors are posing as active players in the communication process, when the basis of their behaviour is participation (Arnstein, 1969). Ideological basis of the participative approach is the concept of 'good governance' (CEC, 2001; UNESCAP, 2008).

According to surveys conducted by the Centre for Social and Economic Strategies, Faculty of Social Sciences, Charles University in Prague (see Frič \& Nekola, 2011), three-fifths of Czech citizens surveyed are 'afraid to come out publicly' and only a third of the polled citizens consider themselves confident and publicly prominent citizens. In the Czech Republic, we encounter the participative approach rather at the local government level when adopting principles of the local Agenda 21 (which is a projection of the principles of sustainable development at the local level - see http://www1.cenia.cz/www/ma21), the project Healthy Cities (see https://www. healthycities.cz/), community planning of social services and so on.

A lack of communication between public administration authorities and the public is one of the causes of strategic governance deficit in the Czech Republic, and also one of the manifestations of deficiency in strategic governance and strategic management. In the Czech Republic, we encounter the passive, selective, as well as participative approach. However, the passive approach dominates. It manifests itself in the indifference of citizens towards the administration of public affairs, in reliance of citizens that public administration authorities themselves solve all the problems.

The aforementioned negative state continues to endure. This is confirmed by the results of the current (yet unfinished) research (interviews) of the staff of the ministries of the Czech Republic who are engaged in strategic activities. Politicians are not interested in acting strategically, nor are they interested in creating projects with long-term time horizons. This problem was succinctly described by a respondent from the Ministry for Regional Development (Respondent E) by the assertion (hypothesis) that the ruling politicians are concerned about the risk that the results of these operations would not be seen until the end of the given election cycle, which carries the risk that this last of results would be favourable to the opposition parties and pave the way for the opposition to use this as an effective election strategy and be victorious in the upcoming vote. This negative state persists also in the negative impact politics on personnel selection. Respondents reported cases in interviews that the political parties that win elections appoint such people to the respective positions who are politically reliable, but not always professionally qualified to exercise effective governance. Unfortunately, this negative phenomenon has not been prevented either by the previously adopted Law on Civil Service (Civil Service Law no. 234/2014), whose creators had set as one of its goals the increase in proficiency in the state administration and the de-politicization of public administration. We discovered, however, 'bad practice'. Interviews with employees of ministries had revealed that the goals mentioned in the civil service law were possible to circumvent, such as the fact that each minister chooses such selection criteria for filling the post of his deputy specialist as to significantly reduce the number of potential candidates while leaving their favourite. The most glaring example of such a placement was for the post of expert deputy minister, which was described by a respondent (respondent A) from the Ministry of Health. This 'bad practice' is also facilitated by the fact that the Czech Republic still has no document (implementing decree) that all ministries set the same selection criteria for the selection of the same work (employee) 
position. These are all negative findings, which may be subject to further detailed scientific research. At the same time, it should warn politicians and government authorities on the need for an effective solution.

\section{CONCLUSION}

It is possible to draw the following conclusions from the carried out research. Regarding the search for an answer to the first research question which was focused on the analysis of changes that went through the idea of 'strategic governance' in the Czech Republic, we note that the situation in the area of strategic governance is analogous to the state of public management in the countries of Central and Eastern Europe, as had been identified several years ago by Wright \& Nemec, eds. (2002), Dunn et al. (2006) and Nemec (2010). Their area of strategic governance regarding the central government of the Czech Republic is consistently underestimated. The Czech Republic maintains its continual reluctance of central governments to act strategically. This attitude is manifested in practice as the indecision of governments in solving serious social problems which have long-term social consequences. The Czech government, therefore, only handles 'fleeting events'. It constructs its decisions on prioritizing the 'present moment', or relies on the self-regulatory function of the market. The result is that the government does not feel the need to strategically govern nor strategically manage. Therefore, either they explicitly reject the idea of a 'strategic governance' and 'strategic management' as a relic of communist centralized planning (liberal-oriented governments), or by not dismissing the idea of 'strategic planning' and 'strategic management' (socially oriented governments), but not applying it in practice. This is most likely caused by a number of factors. The first is the 'low culture' of strategic governance and strategic management in the Czech Republic, as well as an underdeveloped capacity for strategic governance and strategic management at the central government level. The second critical factor is the negative impact of the election cycle has on handcuffing governments where governments are not interested in managing the development of society beyond the horizon of the existing electoral cycle (Plaček et al., 2016). The third factor is the absence of a longer-term time horizon in the decision making of governments. Governments have focused solely on the short and medium term, while not exceeding the given election cycle.

The fourth factor is the deficit in the potential (organizational structure) to exercise strategic control in the ministries of the Czech Republic. While searching for the answer to the second and third research question, we discovered that almost half of the ministries (a total of 6 ministries out of the total 14-ministries) have an element that contains the name 'strategic sector' (or a similar name) in their organizational structures. That in itself does not have to necessarily mean that the ministries do not develop sufficiently strategic activities. However, as the results of two empirical studies on the ministries of the Czech Republic show, there is a considerable deficit of strategic management of the ministries of the Czech Republic. Employees of ministries, who by the nature of their duties should perform strategic activities, spend a significant part of their working time on administrative and operational activities. Their professional capacity and time is 'depleted' by the other 'non-strategic' activities. They prefer the most current and short-term challenges for the future (strategic approach). This leads to demotivation of these groups of workers. It also shows that the section of employees within ministries do not have the necessary professional capacity to perform strategic governance and strategic management. The state administration is facing an educational problem of how to increase the skills of its workers. Additionally, the law on civil service does not provide motivation. A clear career structure for civil servants is not there, which would motivate the civil servants to take effective action.

I have suggested some key issues which need to be comprehensively examined theoretically and solved practically. Summarily speaking, the Czech Republic, already mentioned due to a series of previously mentioned (and probably others, so far unexplored) reasons, has failed to implement the idea of 'strategic governance' and 'strategic management'. It is a likely consequence of such a state of public administration, for which we use the term 'frozen reform of public administration'. We understand this by the fact that if there are government documents for public administration reform (see e.g. the government document 'Smart Administration' for the years 2007 to 2015), these documents remain substantially unfulfilled. They have been 'frozen'. It's one of the consequences (and likewise manifestations) of the low capacity of governments to be able to strategically govern and strategically manage the society. It is a very worrisome situation which calls for a solution. In terms of further scientific research, we consider the above factors as the key issues that should be scientifically studied in further detail. 


\section{ACKNOWLEDGEMENTS}

This paper is processed as an output of the research project P-17 'Science of a society, politics and media within challenges of the time' by the Faculty of Social Sciences, Charles University in Prague, and the project of the Czech Science Foundation Nr. O404/12/725 'Policy Workers in the Czech Public Administration: Practices, Professional Values and Identity' and research project TD 03000018 (OMEGA) 'Using the results of social science research in analytical activities focusing on strategic decision-making and public administration'.

\section{REFERENCES}

Act no. 2/1969 Coll., on the establishment of ministries and other central government authorities of the Czech Republic, as amended.

Aristovnik, A. \&Seljak, J. (2009). Performance budgeting: selected international experiences and some lessons for Slovenia. MPRA Paper No. 15499, posted 4. June 2009 08:29 UTC. Retrieved from http://mpra. ub.uni-muenchen.de/15499/

Arnstein, S. (1969). A Ladder of Citizen Participation. Journal of the American Institute of Planners, 35 (4), 216-224.

Bouckaert, G., Nemec, J. , Nakrošis, V., Hajnal, G. \& Tõnnisson, K. (2009). Public Management Reforms in Central and Eastern Europe. Bratislava: NISPAcee Press.

Colebatch, H. K., Hoppe, R., \& Noordegraaf, M. (Eds.) (2010). Working for Policy. Amsterdam: University Press.

Coombes, D. \&Verheijen, T. (1997). Reforma verejnej správy: Porovnanie skúseností východu a západu [Public administration reform: comparison of West and East experience]. Bratislava: NISPAcee.

De Vries, M. \& Nemec, J. (2013). Public Sector reform: an overview of recent literature and research on NPM and alternative paths. International Journal of Public Sector Management, 26(1), 4-16.

Dunn, N.W., Staroňová, K. \& Pushkarev, S. (2006). Implementation: The Missing Link in Public Administration Reform in Central and Eastern Europe. Bratislava: NISPAcee.

Dror, Y. (2004). Strategic Brain for Central Government. In Potůček, M. (ed.). The Capacity to Govern in Central and Eastern Europe, pp. 15-27. Bratislava: NISPAcee.

Evans, B. M. \& Wellstead, A. (2013). Policy dialogue and engagement between non-governmental organizations and government: A survey of processes and instruments of Canadian policy workers. Central European Journal of Public Policy 7 (1), 6o-87.

Evans, B., Lum, J., \& Shields, J. (2011). The State of Policy Capacity in Canada: Assessments from Senior Public Servants. Presented at the Annual Meeting of the Canadian Political Science Association
May 16-18, 2011. Wilfrid Laurier University, Waterloo, Ontario. Retrieved from: // https://www.cpsa-acsp.ca/papers-2011/Evans1.pdf

Howlett, M. (2009). Policy analytical capacity and evidence-based policy-making: lessons from Canada. Canadian Public Administration, 52 (2), 153-173.

Howlett, M. (2011). Public Managers as the Missing Variable in Policy Studies: An Empirical Investigation Using Canadian Data. Review of Policy Research. 28(3), 247-263.

Forbes, D.P. \& Milliken, F.J. (1999). Cognition and Corporate Governance: Understanding Boards of Directors as Strategic Decision-Making Groups. Academy of Management Review, 24 (3), 489-505.

Frič, P. \& Nekola, M. (2011). Výzva čtvrtá: Elity a veřejnost [Challenge Four: Elites and the Public]. In Potůček, M. et al. Poznávání budoucnosti jako výzva [Cognition of the Future as a Challenge], pp. 55-80. Praha: Nakladatelství Karolinum.

Ghosh, M. \& John, G. (2005). Strategic Fit in Industrial Alliances: An Empirical Test of Governance Value Analysis. Journal of Marketing Research. Vol. XLII (August 2005), 346-357. Retrieved from http:// citeseerx.ist.psu.edu/viewdoc/download?doi=10.1.1.714.2176\&rep=rep1 \&type=pdf

Governance for Human Development (2000). UNDP FRY: December.

Hajek, F. A. (1944). The Road to Serfdom. London: George Routledge and Sons Ltd.

Hajek, F. A. (1979). The Counter-Revolution of Science. Studies on the Abuse of Reason. Indianapolis: Liberty Press.

Hajek, F. A. (1973). Law, Legislation and Liberty. London: Routleger Kegan Ltd.

Harris, B. (2005). Strategic governance. Retrieved from http://www. nonprofitcenter.com

Immergut, E. M. (1998). The Theoretical Core of the New Institutionalism. Politics and Society, 26 (1), 5-34. 
Loorbach, D. (2010). Transition Management for Sustainable Development:APrescriptive, Complexity-Based Governance Framework. Governance: An International Journal of Policy, Administration, and Institutions, 23(1), 161-183.

Montenegro Meyer, L. \& Bulgakov S. (2014). Reflection on ActorNetwork Theory, Governance Networks, and Strategic Outcomes. Brazilian Administration Review., V. 11 (1), art 6, 107-124. Retrieved from http: //www.anpad.org.br/bar.

Mulgan, G. (2004). Strategy in Government. The United Kingdom Experience. In Potůček, M.(ed.). The Capacity to Govern in Central and Eastern Europe, pp. 33-62. Bratislava, NISPAcee.

Nekola, M. \& Kohoutek „I J. (2016). Policy work at the sub-national level: Analytical styles of Canadian and Czech directors and managers. Canadian Public Administration/Administration Publique du Canada. 59(2), 289-309.

Novotný, V. \& Nekola, M. 2010. Strategické rízení a teoretické př́stupy k procesu tvorby veřejných politik (Strategic Management and Theoretical Approaches to Policy-making Process).In Ochrana, F. (Ed.), Drhová, Z., Frič, P., Nekola, M., Novotný, V., Potůček, M. Rašek, A., Simonová, J. \& Veselý, A. Strategické rízení ve veřejné správě a př̌stupy $k$ tvorbě politiky, pp. 61-87. 1. vyd. Praha: Matfyzpress.

Nemec, J. (2010). New Public Management and its Implementation in CEE: What Do we Know and where Do we Go? NISPAcee Journal of Public Administration and Policy. 3 (1), 31-52.

Niskanen, W.A. (1998). Policy Analysis and Public Choice. Selected Papers by William A. Niskanen. Cheltenham, UK - Northampton, MA, USA.

Ochrana, F. \&al. (2010). Strategické ř́zení ve veřejné správě a prístupy ke tvorbě politiky. [Strategic management in public administration and approaches towards policy-making]. Praha: Matfyzpress.

Osborne, D. \& Gaebler, T. (1993). Reinventing Government. How the Entrepreneurial Spirit is Transforming the Public Sector. New York: Penguin Books.

Plaček, M., Půček, M., Ochrana, F. Křápek, M. \& Matějová, L. (2016). Political Business Cycle in the Czech Republic: Case of Municipalities. Prague Economic Papers, 25(3), 304-320. doi:10.18267/j.pep.566.

Pollit, Ch. \& Bouckaert, G. (2004). Public Management Reform. A Comparative Analysis. Second edition. Oxford: University Press.

Potůček, M. (Ed.) (2004). The Capacity to Govern in Central and Eastern Europe. Bratislava, NISPAcee 2004.

Potưček, M. \& al. (2007). Strategické vládnutía Česká republika. [Strategic Governance and the Czech Republic]. Praha: Grada.

Potưček, M. \& al. (2011). Poznávání budoucnosti jako výzva [Discovering Future as a Challenge]. Praha: Karolinum.
Potůček, M. et al. (2016). Veřejná politika (Public policy). Praha: C.H. Beck

Potůček, M. \& Přikryl J. (2007). Strategické vládnutí a Česká republika po roce 1989. [Strategic Governance and the Czech Republic after 1989]. In. Potůček, M. et al. Strategické vládnutí a Česká republika. (Strategic Governance and the Czech Republic), pp. 125-136. Praha: Grada.

Rosenbaum, A., Nemec, J. \& al. (2006). Democratic Governance in CEE Countries: Challenges and Responses for XXI Century. Bratislava: NISPAcee.

Sabatier, P.A. \& Jenkins-Smith, H.C. (1999). The Advocacy Coalition Framework: An Assessment, pp. 117-166. In Sabatier, P.A. (ed.) Theories of the Policy Process. First edition. Boulder (Col.): Westview Press.

Sabatier, P.A. \& Weible, Ch.M. (2007). The Advocacy Coalition Framework: Innovation and Clarifications. In Sabatier, P.A. (ed.). Theories of the Policy Process. Second edition, pp. 189-220. Boulder (Col.): Westview Press.

Van Doeveren, N. (2011). Rethinking Good Governance. Public Integrity, 13(4), 301-318. Advance online publication. doi:10.2753/PIN10999922130401

Veselý, A. (2013). Conducting large-N Surveys on Policy Work in Bureaucracies: Some Methodological Challenges and Implications from the Czech Republic. Central European Journal of Public Policy, 7(2), 88113 .

Veselý, A. (2014). The Profile and Work of Officials in Central and Regional Administration Compared: The Case of the Czech Republic. NISPAcee Journal, 7(1), 107-128.

Veselý, A., Wellstead, A., \& Evans, B. (2014). Comparing sub-national policy workers in Canada and the Czech Republic: Who are they, what they do, and why it matters? Policy and Society, 33(2), 103-115.

Vymětal, P. (2008). What is good governance about? The roots and the key elements of the concept. Working papers, 2(11), 5-17. Prague: Oeconomica. Faculty of International Relations. Wright, G. \& Nemec, J. (Eds.) (2002). Public Management in the Central and Eastern European Transition: Concepts and Cases. Bratislava: NISPA.

Commission of the European Communities (2001). Brussels, 25.7. 2001. Retrieved from: http://www.ab.gov.tr/files/ardb/evt/1_avrupa_ birligi/1_6_raporlar/1_1_white_papers/com2001_white_paper_ european_governance.pdf.

MMR ČR (2013) Metodika prípravy veřejných strategií [Methodology of preparation of public policies]. Praha: Ministerstvo pro místní rozvoj. Retrieved from: http://www.mmr.cz/getmedia/4ebb3cc7-6f $5 c-4 f_{37-}$ ad1f-97054a212483/metodika-pripravy-verejnych-strategii_listopad2012.pdf. 
MV ČR (2007). Efektivní veřejná správa a prátelské veřejné služby, Strategie realizace Smart Administration v obdobi 2007-2015. [Effective Public Administration and Friendly Public Services, Strategy of Implementation of Smart Administration in 2007-2015]. Praha: Ministertvo vnitra. Retrieved from: http://www.mvcr.cz/clanek/verejna-sprava-dokumentymodernizace-dokumenty.aspx.

Místní Agenda 21 [Local Agenda 21]. Retrieved from: http://www1.cenia. $\mathrm{cz} / \mathrm{www} / \mathrm{ma21}$

UNESCAP (2008). What is good governance? United Nations Economic and Social Commission for Asia and the Pacific. Retrieved from: http:// www.unescap.org/resources/what-good-governance.

Schuster, J.H., Smith, D.G., Corak, K.A. \&Yamada, M.M. (1994). Strategic governance: How to Make Big Decisions Better. American Council on Education. Series on Higher Education: ORYX Press.

\section{INTERVIEWS}

a) An interview with respondent A (Ministry of Health, April 4, 2016). Interview conducted by the research project TD 03000018 OMEGA "Using the results of social science research in analytical activities focusing on strategic decision-making and public administration" (project leader A. Veselý). Interview archived on the site: Centre for Social and Economic Strategies, Faculty of Social Sciences, Charles University in Prague.

b) An interview with respondent B (Ministry of Agriculture, March 31, 2016). Interview conducted by the research project TD 03000018 OMEGA "Using the results of social science research in analytical activities focusing on strategic decision-making and public administration" (project leader A. Veselý). Interview archived on the site: Centre for Social and Economic Strategies, Faculty of Social Sciences, Charles University in Prague.

c) An interview with respondent C (Ministry of Defence, interview April 16, 2016). Interview conducted by the research project TD 03000018 OMEGA "Using the results of social science research in analytical activities focusing on strategic decision-making and public administration" (project leader A. Veselý). Interview archived on the site: Centre for Social and Economic Strategies, Faculty of Social Sciences, Charles University in Prague.
Johnson, G., Langley, A., Mein, L.\& Whittington, R. (2007). Strategy as practice: research directions and resources. New York: Cambridge University Press.

Wisser, M. (2016). Management control, accountability, and learning in public sector organizations: A critical analysis. Retrieved from https:// www.researchgate.net/publication/297369634_Management_Control_ Accountability_and_Learning_in_Public_Sector_Organizations_A_ Critical_Analysis.

The Civil Service Act no. 234/2014. Retrieved from: https://www. zakonyprolidi.cz/cs/2014-234. d) An interview with respondent D (Ministry of Finance, interviewed May 5, 2016). Interview conducted by the research project OMEGA TD 03000018 "Using the results of social science research in analytical activities focusing on strategic decision-making and public administration" (project leader A. Veselý). Interview archived on the site: Centre for Social and Economic Strategies, Faculty of Social Sciences, Charles University in Prague.

e) An interview with respondent E (Ministry for Regional Development). The interview was conducted at the request respondent without record. Respondent $E$ has currently left (involuntarily) for another ministry. 